\title{
Trace Metals Geochemistry of Crude Oils from Umutu/Bomu Fields in South West Niger Delta Nigeria
}

\author{
Onojake Mudiaga C. (Corresponding author) \\ Department of Pure and Industrial Chemistry, University of Port Harcourt \\ P.M.B 5323, Choba, Port Harcourt, Nigeria \\ Tel: 234-803-540-4696 E-mail: ononed@yahoo.com; mudiaga.onojake@uniport.edu.ng
}

Oforka Nicolas C.

Department of Pure and Industrial Chemistry, University of Port Harcourt

P.M.B 5323, Choba, Port Harcourt, Nigeria

Tel: 234-803-339-2815Ｅ-mail: oforkanick@yahoo.co.uk

\author{
Osuji Leo C. \\ Department of Pure and Industrial Chemistry, University of Port Harcourt \\ P.M.B 5323, Choba, Port Harcourt, Nigeria \\ Tel: 234-803-340-9338Ｅ-mail: osujileo@yahoo.com
}

Received: November 29, 2011 Accepted: December 8, $2011 \quad$ Published: December 31, 2011

doi:10.5539/eer.v1n1p139 URL: http://dx.doi.org/10.5539/eer.v1n1p139

This research work was carried out in the laboratory of INDORAMA-Eleme petrochemical Company Ltd. East West Road Port Harcourt, Rivers state, Nigeria.

\begin{abstract}
Seven crude oil samples were collected from two oil fields south Niger Delta Nigeria which had not been previously characterized with trace metals and analyzed using Atomic absorption spectroscopy. The concentration of $\mathrm{Fe}$ ranges from 0.38 to $31.53 \mathrm{ppm}, \mathrm{Zn}$ ranges from 0.65 to $80.69 \mathrm{ppm}, \mathrm{Pb}$ ranges from 1.39 to $25.00 \mathrm{ppm}, \mathrm{Cu}$ ranges from 0.26 to $6.43 \mathrm{ppm}, \mathrm{Cr}$ ranges 0.60 to $2.94 \mathrm{ppm}, \mathrm{Cd}$ ranges from 0.09 to $0.33 \mathrm{ppm}, \mathrm{Ni}$ ranges from 0.63 to $8.93 \mathrm{ppm}, \mathrm{Mn}$ ranges from 0.21 to $2.25 \mathrm{ppm}, \mathrm{V}$ ranges 0.30 to $0.72 \mathrm{ppm}$, Co ranges from 0.38 to $0.62 \mathrm{ppm}$. The divergent ratios calculated from the concentration of the trace metals include $\mathrm{V} / \mathrm{Ni}$, $\mathrm{V} /(\mathrm{V}+\mathrm{Ni}), \mathrm{Co} / \mathrm{Ni}$ and $\mathrm{Fe} / \mathrm{V}$, which varies between 0.36 and 0.67 for $\mathrm{V} / \mathrm{Ni}$, between 0.07 and 0.40 for $\mathrm{V} /(\mathrm{V}+\mathrm{Ni})$, between 0.06 and 0.99 for $\mathrm{Co} / \mathrm{Ni}$ and finally between 1.26 and 43.78 for $\mathrm{Fe} / \mathrm{V}$. Two genetic groups of crude oils are identified and the organic matter originated from mixed sources deposited in an oxic environment.
\end{abstract}

Keywords: Organic matter, Genetic groups, Depositional environment, Geochemistry and trace metals

\section{Introduction}

Petroleum consists predominantly of hydrocarbons, and contains measurable quantities of many metals such as $\mathrm{Fe}, \mathrm{Zn}, \mathrm{Ni}, \mathrm{V}, \mathrm{Cr}, \mathrm{Cd}, \mathrm{Cu}, \mathrm{Mn}$, and $\mathrm{Co}$. These trace metals are simply a reflection of those picked up during migration or in the reservoir, and incorporated directly into oils in form of porphyrin complexes (species) in petroleum source rocks from the biomass and formation during sedimentation (Akinlua et al., 2007). It may also involve digenesis from organic molecules as well as metals derived from different biogenic (biomass) and abiogenic (Weathering of minerals) sources. Metals of proven association with organic matter may be used as reliable correlation tools (Akinlua et al., 2007). Nickel, Vanadium and Cobalt (usually referred to as biophile elements) are such examples.

Trace metals are metals occurring at $1000 \mathrm{mg} / \mathrm{kg}$ or less in the earth crust. Depending on their densities, these elements can be classified as light or heavy. Metals with densities greater than $5 \mathrm{~g} / \mathrm{cm}^{3}$ are 'heavy' metals while those with densities less than $5 \mathrm{~g} / \mathrm{cm}^{3}$ are 'light' metals (Osuji and Onojake, 2004). 
The nature of occurrence of trace metals, their distribution patterns and concentration in crude oils can give information on the origin, migration, environment of deposition and maturation of petroleum as well as providing a basis for regional geochemical prospecting (Elirich et al., 1985; Barwise, 1990, Oluwole et al., 1993).

Trace element data of crude oils have been reported to be equally effective in classifying and correlating crude oils and are relative to organic geochemical methods (Lewan, 1984; Curiale, 1987; Udo et al., 1992).

Concentration and ratios of trace metals in crude oils can be used to classify oils into families. For instance low $\mathrm{V} / \mathrm{Ni}$ ratios $(<0.5)$ are expected for petroleum or crude oil derived from marine organic matter, with high to moderate sulphur content. Crude oil or petroleum from lacustrine and terrestrial organic matter has V/Ni ratios (1-10) (Barwise, 1990). Oil from marine organic matter have high concentrations of metals (particularly $\mathrm{Ni}$ and $\mathrm{V}$ ), this is expected for marine source rocks where there is an abundant input of porphyrin - precursor chlorophylls to the organic matter derived from algae and bacteria (Barwise, 1990). Moderate quantities of metals are found in oils derived from lacustrine source rocks while little nickel and vanadium is found in land-plant derived oils.

In this study, trace metals associated with crude oils have been used to investigate the characteristics of crude oils from two (2) fields in the south west Niger Delta with the objective of understanding the type and quality of crude oils, their correlation, degree of thermal maturity, organic matter source and depositional environment. The two fields under investigation have not been characterized hitherto with trace metals indices.

\subsection{Description of study area}

The Niger Delta is one of the world's largest Tertiary delta systems and an extremely prolific hydrocarbon province. It lies between $4^{\circ} 17^{\prime}$ and $6^{\circ} 18^{\prime}$ North latitude and $4^{\circ} .99^{\prime}$ and $7^{\circ} 89^{\prime}$ East longitude (Figure 1). It is situated on the West African continental margin at the apex of the Gulf of Guinea (Doust, 1990). It occupies an area of about $75,000 \mathrm{~km}^{2}$ with clastic sequence which reaches a maximum thickness of 9,000 to $12,000 \mathrm{~m}$ of sediment and a total sediment volume of $500,000 \mathrm{~km}^{3}$ ( Adedosu and Sonibare, 2005).

Stratigraphically, the thick sedimentary sequence is made up of three principal lithostratigraphic units namely, the Benin, Agbada and Akata formations (Short and Stauble, 1967). The Benin formation is the alluvial or upper coastal plain depositional environment of the Niger Delta complex. It consists of mainly fluviatile gravels and sands. It has a thickness in excess of $1820 \mathrm{~m}$.

The Agbada formation underlies the Benin formation and is made up primarily of alternating sandstones and shales which are of fluvio-marine origin. The Akata formation is the lowest unit of the Niger Delta complex. It was deposited in a typical marine environment.

The hydrocarbon habitat of the Niger Delta is mostly within the sandstones reservoir of the Agbada formation where they are usually trapped in over anticlines associated with growth faults.

\section{Materials and Methods}

\subsection{Sample collection and analyses}

Seven crude oil samples were collected at stratigraphic depths ranging from 10500 to $11200 \mathrm{ft}$ in two producing fields Umutu and Bomu onshore south west Niger delta (Figure 1) using glass vials with Teflon caps which were pre - rinsed with trioxonitrate (v) acid and distilled water and properly dried. The crude oil samples were then placed in a box containing ice packs, stored at a temperature of about $4^{\circ} \mathrm{C}$ prior to laboratory analysis.

Approximately $1 \mathrm{~g}$ of crude oils were digested and diluted to $50 \mathrm{~cm}^{3}$ with reagents (trioxonitrate $(\mathrm{v})$ acid and hydrogen peroxide). The digested samples were then analyzed for trace metal using Perkin - Elmer model 2280/2380 atomic- absorption spectrophometer (AAS).

\section{Results and Discussion}

The concentration of trace metals and their ratios in crude oils can be used to classify oils into genetic families. Table 1 shows the concentration of some of the trace metals associated with crude oils and their ratios. The concentration of Fe ranged from $0.38-31.52 \mathrm{ppm}$ with an average of $9.36 \mathrm{ppm}$. The values are lower than those of Ekweozor et al., 1979 and higher than those of Udo et al., 1992; Oluwale et al., 1993 and Nwachuku et al., 1995 for Niger delta crude oils. The concentration of $\mathrm{V}$ ranged from $0.30-0.72$ with an average of 0.50 . The values are within the ranges observed by Nwachukwu et al., 1995; Oluwole et al., 1993; Ndiokwere, 1983 but lower than the values obtained by Udo et al., 1992 for Niger Delta crude oils. The concentration of V are higher in samples KD01, KD02 and KD03 than samples U2T, U7L, U45 and U4L which is a reflection of high 
terregenous (Land plant) input in the former than the latter samples. Figure 2 is a cross plot of the concentration of $\mathrm{V}$ versus $\mathrm{Fe}$. This plot clearly separates the crude oil samples into two (2) genetic families.

The concentrations of $\mathrm{Zn}$ ranged from $0.65-80.69 \mathrm{ppm}$ with an average of $27.56 \mathrm{ppm}$. The values of $\mathrm{Zn}$ are higher in KD01, KD02 and KD03 samples compared to the U2T to U4L samples. $\mathrm{Pb}, \mathrm{Cu}, \mathrm{Cr}, \mathrm{Cd}, \mathrm{Ni}$ and $\mathrm{Mn}$ have the same concentration in samples U2T, U7L, U45 and U4L with their values as $1.39,0.26,0.60,0.09,0.63$ and $0.21 \mathrm{ppm}$ respectively. The concentration of these trace metals varied in samples KD01, KD02 and KD03 with ranges of $8.33-16.67 \mathrm{ppm}$ for $\mathrm{Pb} ; 2.14-6.43 \mathrm{ppm}$ for $\mathrm{Cu} ; 2.94 \mathrm{ppm}$ for $\mathrm{Cr}$, $0.33 \mathrm{ppm}$ for $\mathrm{Cd}, 1.79-8.93$ ppm for Ni and $0.56-2.25 \mathrm{ppm}$ for Mn. The concentration of $\mathrm{V}$ was also found to be higher in KD01, KD02 and KD03 with ranges of $0.65-0.72 \mathrm{ppm}$ and lesser in the first four samples with ranges of $0.30-0.42 \mathrm{ppm}$. The higher value of $\mathrm{V}$ in these groups of crude oils reflects high terregenous input in the oils samples.

The concentration of Co is higher in samples U2T, U7L, U45L U4L with values of $0.62,0.56,0.58$ and 0.59 ppm than KD02, KD02 KD03 with values of $0.53,0.49$ and $0.46 \mathrm{ppm}$. The values are in agreement with the work of Nwachukwu et al., 1995; Udo et al., 1992; Oluwole et al., 1993 but lower than those of Ndiokwere, 1983.

\subsection{Ratios of transition metals}

The concentrations and ratios of trace metals such as V, Ni and Co are of particular importance in trace metal geochemistry. These ratios are used in the determination of source rocks types, depositional environment and maturation of crude oils. This is because these ratios remain unchanged irrespective of digenetic and in reservoir alteration (Lewan, 1984; Barwise, 1990 and Udo et al., 1992).

The calculated V/Ni ratios are lower in samples KD01, KD02 and KD03 which ranged from $0.08-0.36 \mathrm{mg} / \mathrm{L}$. and higher in samples U2T, U7L, U45L and U4L which ranged from $0.48-0.67 \mathrm{mg} / \mathrm{L}$. Udo et al., 1992, reported that the V/Ni ratio decreases with increasing maturity. The lower V/Ni ratios are typically of terrestrially derived source rocks (Barwise, 1990; Udo et al., 1992 and Nwachukwu et al., 1995). This suggests that the former groups of samples are more matured than the later. Again the variation in the values of V/Ni ratio also suggests that the crude oil samples are from different sources of organic matter.

The ratio of $\mathrm{V} / \mathrm{V}+\mathrm{Ni}$ for the samples ranges from $0.07-0.40$. This ratio is higher in the first four samples compared to the last three crude oil samples. This is in good agreement with those obtained by Nwachukwu et al., (1995) who used these values to classify oils derived from terrestrial organic matter.

The Co/Ni ratios are shown in Table 1. The values range from $0.06-0.99$. The values are lower in crude oil samples KD01, KD02 and KD03. Udo et al., 1992 interpreted ratios greater 0.1 to indicate oil from source rocks that have more of marine organic input. From Table 1, samples U2T, U7L, U45, U4L and KD03 are greater 0.1 depicting the claim. Figure 3 is a crossplot of the ratio of $\mathrm{Co} / \mathrm{Ni}$ versus $\mathrm{V} / \mathrm{Ni}$. This ratio grouped the crude oil samples into two distinct genetic families.

\subsection{Cluster analysis}

Figure 4 is Cluster analysis of API gravity and total transition metals (TTM) variables while Figure 5 is cluster analysis of $\mathrm{V} / \mathrm{V}+\mathrm{Ni}$ variable. It is observed that Figure 4 grouped the oils into two major subgroups at $60.3 \%$ similarity and $73.6 \%$ respectively. At $75 \%$ the samples were further separated into closer similarity. Figure 5 is a plot of $\mathrm{V} / \mathrm{V}+\mathrm{Ni}$. The dendrogram shows that at $43.9 \%$ the crude oil samples were separated into two major subgroups. At $54.2 \%$ similarity the crude oils were also group into closer subgroup. $80 \%$ similarity further reveals a closer relationship among the crude oil samples.

\subsection{Inter metal correlations}

Table 2 shows the relationship between the trace metals, API gravity and TTM. A unique observation is the strong positive correlation of the metals with each other except Co which correlates negatively with all the metals. This may be an indication of a common origin or close genetic relationship. API gravity shows a negative correlation with all trace metals because their effects on crude oils are usually opposite (Nwachukwu et al., 1995).

\section{Conclusion}

Examination of the trace metals characteristics of the crude oils under study showed two distinct genetic families of crude oils with similar genetic characteristics but different sources. This study also reveals that the oils were derived from source rocks containing mixed kerogen (marine and terrestrial) deposited in an oxic environment. This claim is supported by a crossplot of the ratio of $\mathrm{Co} / \mathrm{Ni}$ versus $\mathrm{V} / \mathrm{Ni}$ which equally reveals two distinct 
groups of oils. A strong positive correlation of the metals with each other buttresses a common origin or close genetic relationship of the studied oil samples.

\section{Acknowledgements}

The authors and sincerely grateful to the Nigerian Department of Petroleum Resource (DPR) and Platform Petroleum Limited Nigeria for granting us access to the crude oils samples used for this research work. We also appreciate the effort of Mr. Oteiva, Frank M of Chromatography Laboratory, INDORAMA- Eleme petrochemical Company Ltd for his assistance during the laboratory analyses.

\section{References}

Adedosu, T. A., \& Sonibare, O. O. (2005). Characterization of Niger Delta crude oil by infrared spectroscopy. Journal of Applied Sciences, 5, 906-909. http://dx.doi.org/10.3923/jas.2005.906.909

Akinlua, A. Ajayi, T. R. and Adeleke, B. B. (2007). Organic and inorganic geochemistry of northwestern Niger Delta oils. Geochemical Journal, 41, 271-281. http://dx.doi.org/10.2343/geochemj.41.271

Barwise, A. J. G. (1990). Role of nickel and vanadium in petroleum classification. Energy and Fuels, 4, 647-652. http://dx.doi.org/10.1021/ef00024a005

Curiale, J. A. (1987). Distribution of transition metals in North Alaska oils. Metal Complexes in Fossil Fuels (Filby, R. H. and Branthaver, J. F., eds.). Am. Chem. Soc. Symp., Series 344, 135-145.

Doust, H., Omatsola, E. (1990). Niger Delta divergent/passive margin basins. AAPG Bull. Mem., 45, 201-238.

Ekweozor, C, M., \& Okogun, J. I., Ekong, D. U. E. and Maxwell, J. R. (1979). Preliminary organic geochemical studies of samples from the Niger Delta, Nigeria. Part 1: Analysis of oils for triterpanes. Chem. Geol., 27, 11-28. http://dx.doi.org/10.1016/0009-2541(79)90100-1

Elirich, J., Hirner, A. V. and Stark, H. (1985). Distribution of trace elements in crude oils from southern Germany. Chem. Geol., 48, 313-323. http://dx.doi.org/10.1016/0009-2541(85)90056-7

Lawan, M. D. (1984). Factors controlling the proportionality of vanadium to nickel in crude oils. Geochemistry Cosmochim. Acta, 48, 2231-2238. http://dx.doi.org/10.1016/0016-7037(84)90219-9

Ndiokwere, C. L. (1983). Analysis of Nigerian petroleum for trace elements by neutron activation. Radiochem. Radioanal. Lett., 59(4), 201-212.

Nwachukwu, J. I., Oluwole, A. F., Asubiojo, O. I., et al. (1995). A geochemical evaluation of Niger Delta crude oils, in Oti, M. N., and Postma. eds, Geology of Deltas. Rotterdam, A. A. Balkema, p. 287

Oluwole, A. F., Asubiojo, O. I., Nwachukwu, J. I., et al. (1993). Neutron activation analysis of Nigerian crude oil. J. Radioanal. Nuclear Chem., 168(1), 145-152. http://dx.doi.org/10.1007/BF02040887

Osuji, L. C., \& Onojake, C. M. (2004). Trace Heavy Metal Associated with Crude Oil: a Case Study of Ebocha8 Oil- spill Polluted Site in Niger Delta, Nigeria. Chemistry and Biodiversity, 1, 1708-1715. http://dx.doi.org/10.1002/cbdv.200490129

Short, K. C., \& Stauble, A. J. (1967). Outline of geology of Niger Delta. AAPG, 51, 761-779.

Udo, O. T., Ekwere, S. and Abrakasa, S. (1992). Some trace metal in selected Niger Delta crude oils: application in oil oil correlation studies. J. Min. Geol., 28(2), 289-291. 
Table 1. Concentrations of some trace metals associated with crude oils and their ratios

\begin{tabular}{|c|c|c|c|c|c|c|c|c|c|c|c|c|c|c|c|}
\hline Sample & $\mathrm{Fe}$ & $\mathrm{Zn}$ & $\mathrm{Pb}$ & $\mathrm{Cu}$ & $\mathrm{Cr}$ & $\mathrm{Cd}$ & $\mathrm{Ni}$ & $\mathrm{Mn}$ & $\mathrm{V}$ & $\mathrm{Co}$ & $\mathrm{TTM}$ & $\mathrm{V} / \mathrm{Ni}$ & $\mathrm{Co} / \mathrm{Ni}$ & $\mathrm{V} / \mathrm{V}+\mathrm{Ni}$ & $\mathrm{Fe} / \mathrm{V}$ \\
\hline U2T & 0.38 & 0.65 & 1.39 & 0.26 & 0.60 & 0.09 & 0.63 & 0.21 & 0.30 & 0.62 & 5.12 & 0.48 & 0.99 & 0.32 & 1.26 \\
\hline U7L & 17.42 & 6.97 & 1.39 & 0.26 & 0.60 & 0.09 & 0.63 & 0.21 & 0.40 & 0.56 & 28.53 & 0.64 & 0.90 & 0.39 & 43.56 \\
\hline U45 & 3.03 & 0.93 & 1.39 & 0.26 & 0.60 & 0.09 & 0.63 & 0.21 & 0.42 & 0.38 & 7.93 & 0.67 & 0.61 & 0.40 & 7.22 \\
\hline U4L & 2.27 & 0.86 & 1.39 & 0.26 & 0.60 & 0.09 & 0.63 & 0.21 & 0.31 & 0.59 & 7.20 & 0.50 & 0.94 & 0.33 & 7.33 \\
\hline KD 01 & 7.61 & 63.37 & 16.67 & 4.29 & 2.94 & 0.33 & 8.93 & 2.25 & 0.68 & 0.53 & 107.59 & 0.08 & 0.06 & 0.07 & 11.19 \\
\hline KD 02 & 31.52 & 80.69 & 8.33 & 6.43 & 2.94 & 0.33 & 5.36 & 1.69 & 0.72 & 0.49 & 138.50 & 0.13 & 0.09 & 0.12 & 43.78 \\
\hline KD 03 & 3.26 & 39.44 & 25.00 & 2.14 & 2.94 & 0.33 & 1.79 & 0.56 & 0.65 & 0.46 & 76.57 & 0.36 & 0.26 & 0.27 & 5.02 \\
\hline Ave & 9.36 & 27.56 & 7.94 & 1.99 & 1.60 & 0.20 & 2.65 & 0.76 & 0.50 & 0.52 & 53.06 & 0.41 & 0.55 & 0.27 & 17.05 \\
\hline
\end{tabular}

Table 2. Pearson's correlation matrix of trace metals and API gravity

\begin{tabular}{|l|l|l|l|l|l|l|l|l|l|l|l|l|}
\hline & $\mathrm{Fe}$ & $\mathrm{Zn}$ & $\mathrm{Pb}$ & $\mathrm{Cu}$ & $\mathrm{Cr}$ & $\mathrm{Cd}$ & $\mathrm{Ni}$ & $\mathrm{Mn}$ & $\mathrm{V}$ & $\mathrm{Co}$ & $\mathrm{TTM}$ & API \\
\hline $\mathrm{Fe}$ & 1.00 & & & & & & & & & & & \\
\hline $\mathrm{Zn}$ & 0.65 & 1.00 & & & & & & & & & & \\
\hline $\mathrm{Pb}$ & -0.03 & -0.03 & 1.00 & & & & & & & & & \\
\hline $\mathrm{Cu}$ & 0.70 & 0.70 & 0.49 & 1.00 & & & & & & & & \\
\hline $\mathrm{Cr}$ & 0.39 & 0.93 & 0.86 & 0.87 & 1.00 & & & & & & & \\
\hline $\mathrm{Cd}$ & 0.39 & 0.93 & 0.86 & 0.87 & 1.00 & 1.00 & & & & & & \\
\hline $\mathrm{Ni}$ & 0.38 & 0.85 & 0.51 & 0.83 & 0.78 & 0.78 & 1.00 & & & & & \\
\hline $\mathrm{Mn}$ & 0.47 & 0.91 & 0.50 & 0.89 & 0.81 & 0.81 & 0.99 & 1.00 & & & & \\
\hline $\mathrm{V}$ & 0.53 & 0.95 & 0.77 & 0.89 & 0.96 & 0.96 & 0.78 & 0.82 & 1.00 & & & \\
\hline $\mathrm{Co}$ & -0.09 & -0.22 & -0.30 & -0.20 & -0.29 & -0.29 & -0.07 & -0.09 & -0.45 & 1.00 & & \\
\hline $\mathrm{TTM}$ & 0.67 & 1.00 & 0.64 & 0.97 & 0.93 & 0.93 & 0.83 & 0.88 & 0.96 & -0.23 & 1.00 & \\
\hline API & -0.36 & -0.76 & -0.76 & -0.68 & -0.83 & -0.83 & -0.63 & -0.65 & -0.81 & 0.14 & -0.78 & 1.00 \\
\hline
\end{tabular}




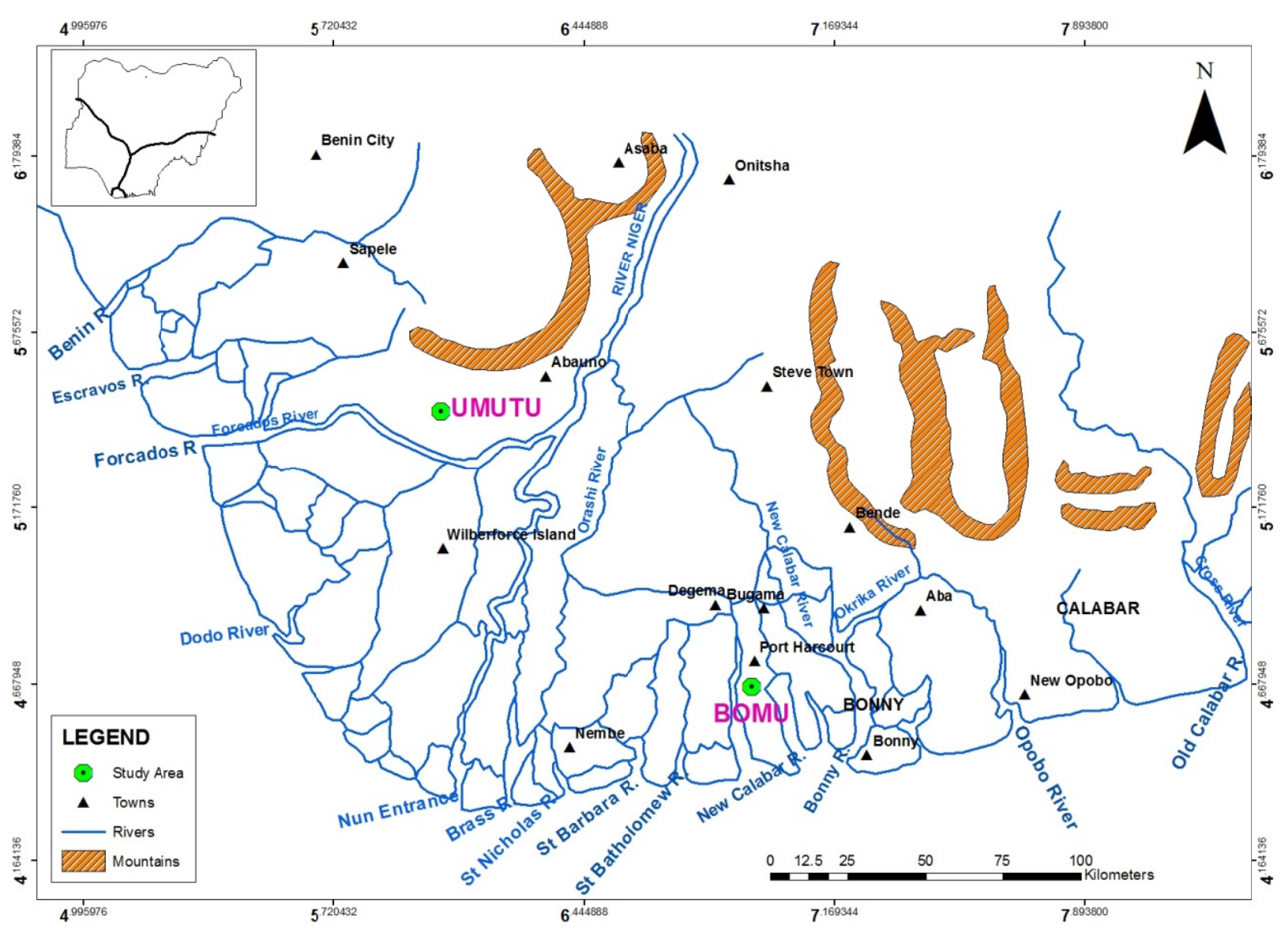

Figure 1. Map of Niger Delta showing the Study Locations

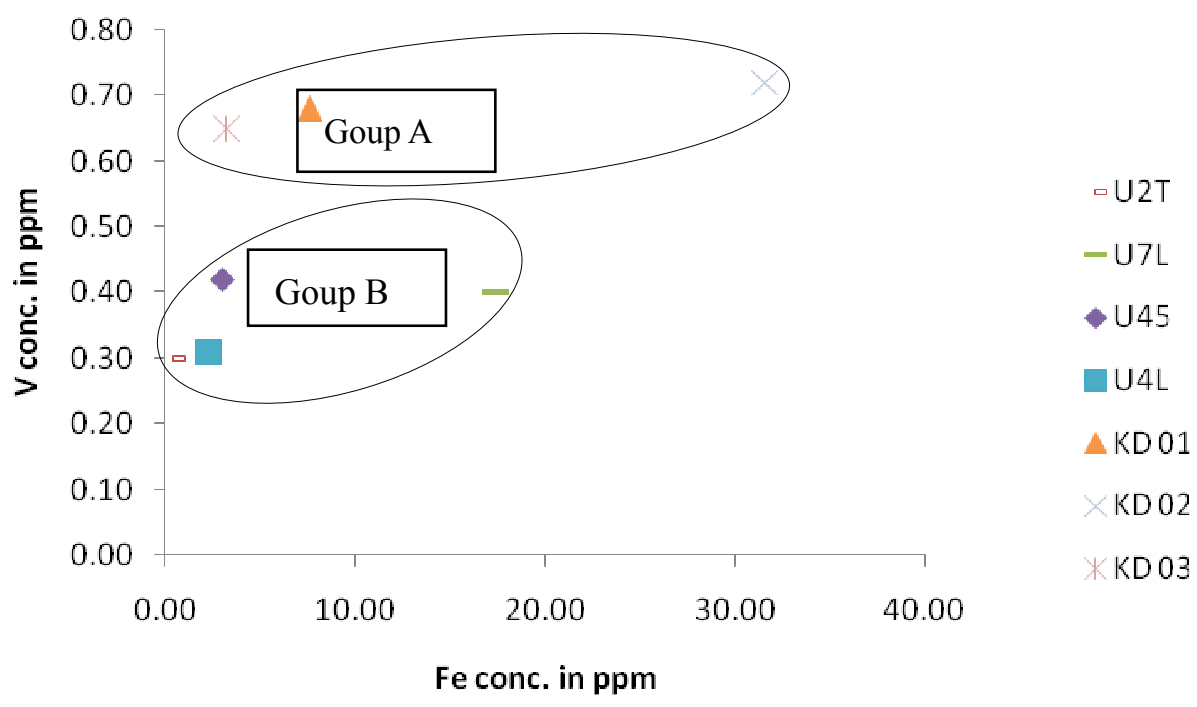

Figure 2. Vanadium concentration versus Iron concentration 


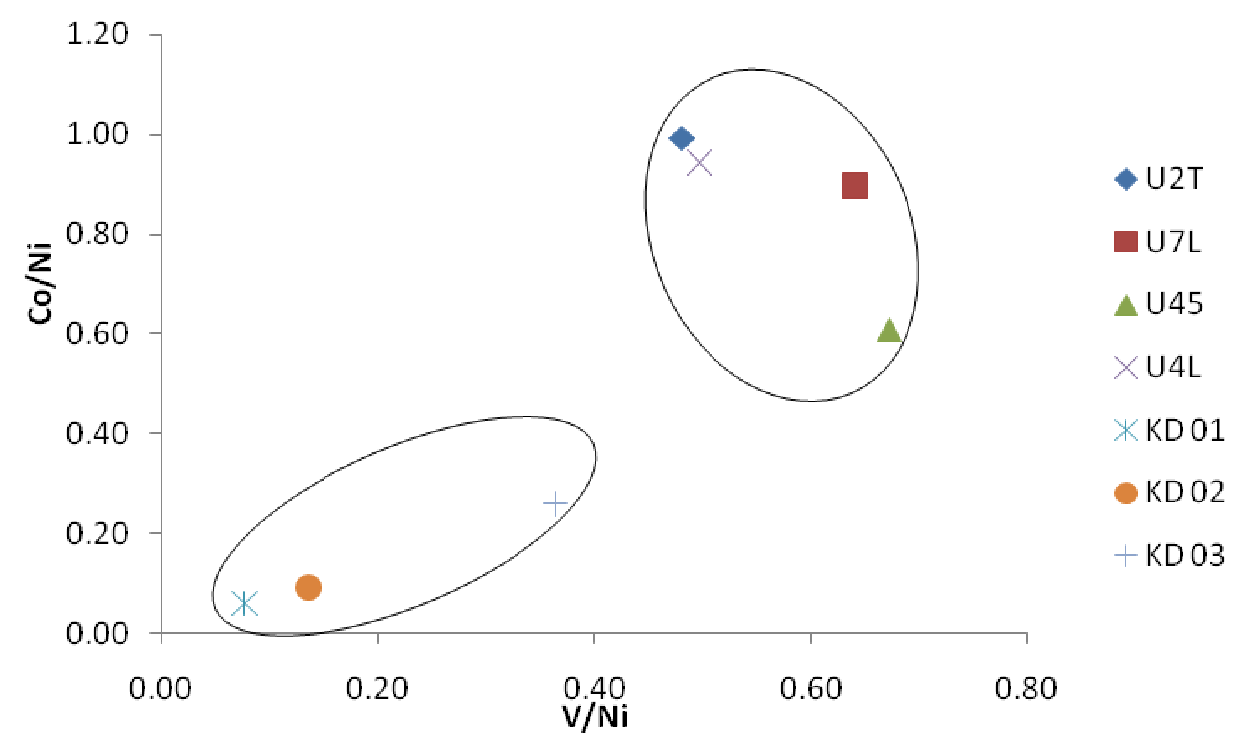

Figure 3. Crossplot of $\mathrm{Co} / \mathrm{Ni}$ versus $\mathrm{V} / \mathrm{Ni}$

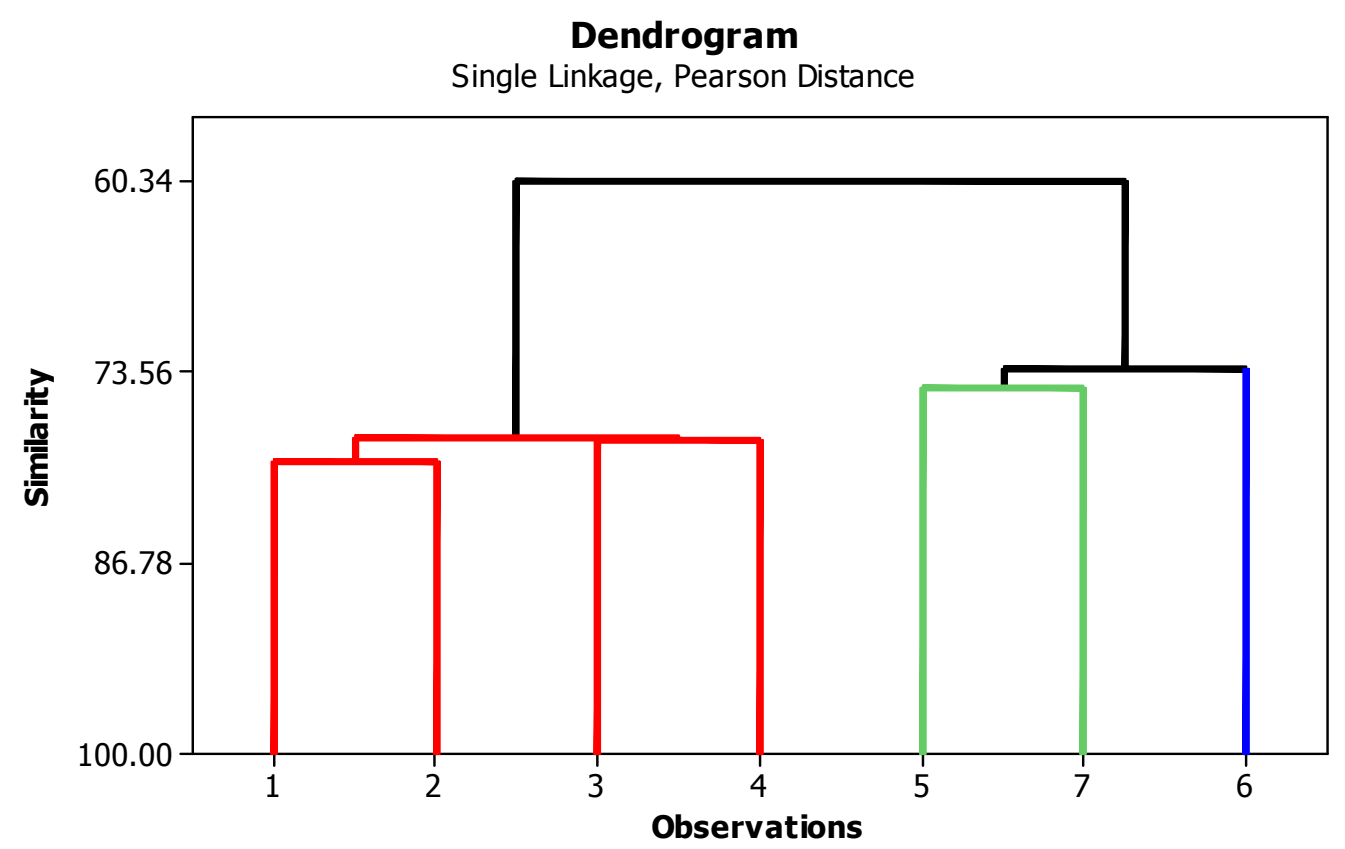

Figure 4. Cluster analysis using API + TTM variables 


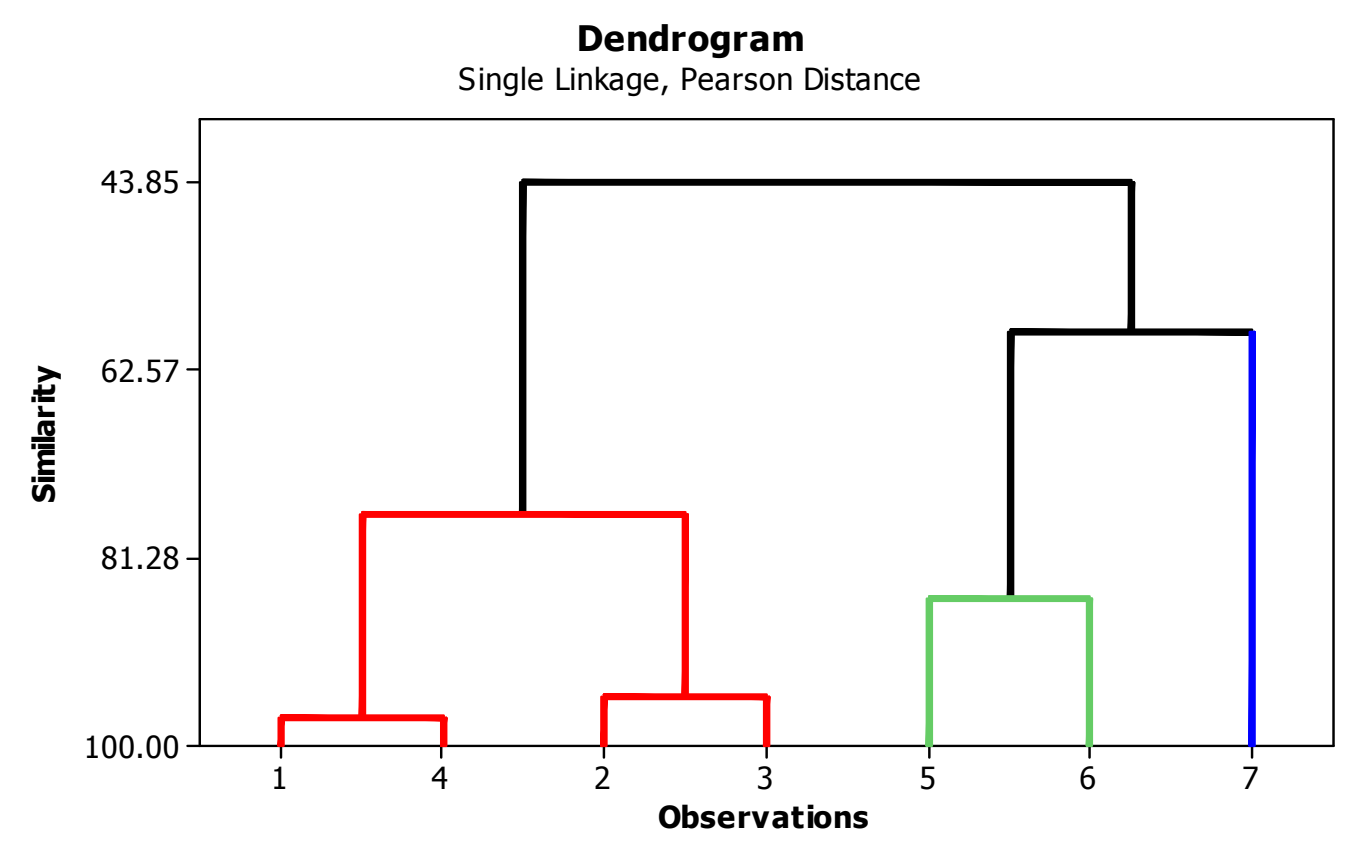

Figure 5. Cluster analysis using $\mathrm{V} / \mathrm{V}+\mathrm{Ni}$ variable 